\title{
First Movement
}

National Cancer Institute

\section{Source}

National Cancer Institute. First Movement. NCI Thesaurus. Code C92797.

An initial set of movements by the fetus that is observed by the pregnant mother. 